\title{
Mechanical aspects of wellbore stability in shales and coals
}

\section{Stateczność otworów w warstwach łupków oraz węgli}

\author{
Tadeusz Szpunar, Paweł Budak \\ Oil and Gas Institute - National Research Institute
}

ABSTRACT: This paper presents a simple model which can be used to calculate the following values:

- critical depth for which the well integrity is preserved in a shale or coal horizon with actual shale/coal mechanical parameters, actual mud density and reservoir parameters;

- minimum mud density at which stress concentration at the wellbore wall is below the allowable limit for a given rock's mechanical parameters, formation pressure gradient, and overburden pressure gradient;

- mud density required for the preservation of shale/coal integrity at the wellbore wall at any depth, assuming that the strength parameters of shale or coal, formation pressure gradient, and overburden pressure gradient are constant.

The appropriate equations were derived using the maximum principal strain hypothesis, which holds for brittle materials. It was also assumed that the radial pressure at the borehole wall is caused by the weight of overburden rocks. The author's intention was to provide formulas which are as simple as possible and which can be easily used in practice. The final equations were based on the solution to the Lame problem, which was adopted to represent a vertical drilling well with a circular cross-section and filled with mud whose hydrostatic pressure is assumed to oppose the pore pressure. Included are effects of silt swelling pressure, overburden pressure, mud density and the mechanical properties of the rock - including the unconfined compressive strength and Poisson's ratio. In the case of shale or silty coal layers, the swelling pressure increases the volume of the clay minerals in the pores by diffusion the mud filtrate, which reduces the pore volume and increases the pore pressure, and therefore impacts the calculations. Presented model allows for derivation of the Hubert-Willis formula for fracturing pressure or fracture pressure gradient, which are commonly used in the oil industry. The calculation results are presented using data from the domestic oil industry and data from one of the Polish coal mines.

Key words: well stability, shale/coal mechanical parameters, unconfined compressive strength, Poisson's ratio, swelling pressure, overburden pressure, mud density.

STRESZCZENIE: W artykule podano prosty model umożliwiający obliczenie następujących wielkości:

- głębokości krytycznej, w jakiej pokład łupków lub węgla zachowa integralność przy danych parametrach mechanicznych łupku lub węgla, danej gęstości płuczki i znanych parametrach złożowych;

- minimalnej gęstości płuczki, przy której koncentracja naprężeń na ścianie otworu nie przekracza granicy dopuszczalnej dla danych parametrów mechanicznych łupku lub węgla oraz gradientu ciśnienia i nadkładu;

- gęstości płuczki, przy której zachowana będzie integralność ścian otworu w warstwach łupku lub węgla w każdej głębokości dla danych parametrów mechanicznych łupku, przy stałym gradiencie ciśnienia i nadkładu.

Wyprowadzono odpowiednie wzory, przyjmując hipotezę wytrzymałościową maksymalnego wytężenia materiału stosowaną w przypadku materiałów kruchych. Przyjęto również, że przy założeniu odkształceń sprężystych ciśnienie radialne na ścianie otworu jest spowodowane ciężarem skał nadkładu. Intencją autorów było podanie możliwie jak najprostszych wzorów, które mogłyby zostać zastosowane w praktyce. Wykorzystano rozwiązania tzw. problemu Lamégo, to jest rozpatrywano stan naprężeń na ścianie pionowego wyrobiska o przekroju kołowym, traktując skałę jako materiał sprężysty. We wzorach na wielkość naprężeń na ścianie wyrobiska o przekroju w kształcie okręgu uwzględniono wpływ ciśnienia pęcznienia, ciśnienia wywieranego przez nadkład, gęstość płuczki, jak również parametry wytrzymałościowe łupku/węgla, w tym wytrzymałość na ściskanie w jednoosiowym stanie naprężeń i współczynnik Poissona. W przypadku warstw łupków lub węgli zailonych ciśnienie pęcznienia powoduje zwiększenie objętości minerałów ilastych w porach w wyniku dyfuzji filtratu płuczki, co zmniejsza objętość porów i zwiększa ciśnienie porowe, a zatem wpływa na wyniki obliczeń. Przedstawiony model pozwala na wyprowadzenie z niego powszechnie stosowanego w przemyśle wzoru Huberta-Willisa, podającego wielkość ciśnienia szczelinowania skał na ścianie otworu oraz gradientu ciśnienia szczelinowania. Przedstawiono wyniki obliczeń dla danych z otworów z krajowego przemysłu naftowego oraz jednej z polskich kopalni węgla kamiennego.

Słowa kluczowe: stateczność otworu, parametry mechaniczne łupka/węgla, wytrzymałość na ściskanie, współczynnik Poissona, ciśnienie pęcznienia, ciśnienie nadkładu, gęstość płuczki.

Corresponding author: P. Budak, e-mail: pawel.budak@inig.pl

Article contributed to the Editor: 03.03.2021. Approved for publication: 02.07.2021 


\section{Introduction}

Silt rocks (mainly shales) constitute 75 percent of all rocks encountered while drilling and are blamed for 90 percent of all drilling problems, such as wellbore instability, heaving shales, bit balling, loss of circulation, pipe sticking, and the like. The majority of these problems are believed to be caused by incompatibility of the drilling mud and rock, resulting in chemical reactions at the mud-rock interface and causing clay to swell and borehole stability to decrease (Gomez and He, 2012; Wang et al., 2017). Whilst we share this opinion, we believe that at least some of the cases of wellbore instability can be explained by rock mechanics, assuming that the state of stress at the wellbore wall is as depicted in this paper. If the shale contains silt minerals, they may swell in contact with water-based mud - this decreases the pore volume and increases the pore pressure. This additional pressure increase (called swelling pressure) may be included in the calculations by adding it to pore pressure (Koteeswaran et al., 2018). The problem of mud impact on shales has been extensively discussed in the literature and is well known to mud and drilling engineers - thus it will not be discussed here (Santarelli i et al., 1992; Mody and Hale, 1993; Van Oort et al., 1994; Santarelli and Carminati, 1995; Gomez and He, 2012; Lyu et al., 2015; Wang et al., 2017). The problem of borehole stability was considered here using the very fundamental principles of rock mechanics. The authors' intention was to provide formulas which are as simple as possible and which can be easily used in practice. The presented approach yields results which seem to be reasonable. The derivation of Equations (4)-(6) uses the very fundamental principles of rock mechanics, but the authors did not find any examples in the literature that take into account the influence of pore pressure, swelling pressure, and rock mechanical parameters on the stability of a well filled with drilling mud of a known density.

\section{Wellbore stability in shales and coals}

The equations derived in the following chapter allow the values specified below to be calculated, provided that shale/coal strength properties - such as Poisson's ratio $\mu$ and unconfined compressive strength $R_{c}$ - as well as the average density of overburden rocks, actual mud density, and pore pressure are known. The mud compatibility, which is believed to be the most important factor influencing wellbore stability in shale, is not considered in the presented model. The values which can be calculated are as follows:

a) critical depth $\left(z_{\text {crit }}\right)$, which is a maximum depth at which a shale/coal of known strength properties maintains its integrity for a known overburden pressure gradient, pore pressure gradient, and mud density;

b) minimum mud density $\rho_{\min }$, which is required to maintain wellbore stability in shales/coals of known strength properties deposited at an actual depth $z$;

c) mud density $\rho_{\max }$, for which a shale/coal with known strength properties preserves its integrity at the wellbore wall for any depth assuming that the overburden pressure gradient and pore pressure gradient are constant.

The equations which define the values mentioned in $a), b$ ), and c) were derived assuming the state of stress at the borehole wall described in detail in the section below. The equations given below were derived using the fundamental principles of rock mechanics.

Formulas which define the critical depth $\left(z_{\text {crit }}\right)$ and the minimum and maximum mud pressure gradient $\left(\gamma_{m_{\text {min }}}\right.$ and $\gamma_{m_{\max }}$ ) required to maintain wellbore stability in shales/coals of known strength properties deposited at an actual depth $z$ and an average pressure gradient of overburden rocks $\gamma_{s}$ are given below:

$$
\begin{gathered}
z_{\text {crit }}=\frac{-\frac{\mu}{1+\mu} R_{c}}{\gamma_{s} \frac{2 \mu^{2}}{1-\mu^{2}}+\alpha \frac{1-3 \mu^{2}}{1-\mu^{2}}-\gamma_{p}} \\
\gamma_{\text {min }}=\gamma_{s} \frac{2 \mu^{2}}{1-\mu^{2}}+\alpha \frac{1-3 \mu^{2}}{1-\mu^{2}}+\frac{R_{c}}{z} \frac{\mu}{1+\mu} \\
\gamma_{m_{\text {max }}}=\gamma_{s} \frac{2 \mu^{2}}{1-\mu^{2}}+\alpha \frac{1-3 \mu^{2}}{1-\mu^{2}}
\end{gathered}
$$

Equations (1)-(3) in SI units are as follows:

$z_{c r i t}[\mathrm{~m}]=\frac{-\frac{\mu}{1+\mu} R_{c}}{9.81 \cdot 10^{-6} \rho_{s} \frac{2 \mu^{2}}{1-\mu^{2}}+\alpha \frac{1-3 \mu^{2}}{1-\mu^{2}}-9.81 \cdot 10^{-6} \rho_{m}}$

$$
\begin{aligned}
\rho_{m \text { min }}\left[\frac{\mathrm{kg}}{\mathrm{m}^{3}}\right]= & \rho_{s} \frac{2 \mu^{2}}{1-\mu^{2}}+1.02 \cdot 10^{5} \alpha \frac{1-3 \mu^{2}}{1-\mu^{2}}- \\
& -1.02 \cdot 10^{5} \frac{R_{c}}{z} \frac{\mu}{1+\mu}
\end{aligned}
$$

$$
\rho_{m \max }\left[\frac{\mathrm{kg}}{\mathrm{m}^{3}}\right]=\rho_{s} \frac{2 \mu^{2}}{1-\mu^{2}}+1.02 \cdot 10^{5} \alpha \frac{1-3 \mu^{2}}{1-\mu^{2}}
$$

where:

$R_{c}$ - unconfined compressive strength of rock $\left(R_{c}<0\right)[\mathrm{MPa}]$,

$\mu$ - Poisson's ratio, dimensionless,

$\rho_{s}$ - average density of overburden rocks $\left[\mathrm{kg} / \mathrm{m}^{3}\right]$,

$\rho_{m}-$ mud density $\left[\mathrm{kg} / \mathrm{m}^{3}\right]$,

$\rho_{m_{\text {min }}}-$ minimum mud density required to maintain wellbore stability $\left[\mathrm{kg} / \mathrm{m}^{3}\right]$, 
$\rho_{m_{\max }}-$ maximum mud density required to maintain wellbore stability at any depth for a given rock's parameters $\left[\mathrm{kg} / \mathrm{m}^{3}\right]$,

$\alpha-$ pore pressure gradient $=$ pore pressure $/$ depth $[\mathrm{MPa} / \mathrm{m}]$, and

$z$ - depth $[\mathrm{m}]$.

If a well stays empty (no mud inside, $\rho_{m}=0$ ) and the influence of pore pressure on wellbore stability is omitted $(\alpha=0$, solid rock with no porosity), then Equation (4) yields the depth which the well will tolerate without being cased. Equation (4) is very similar to the formula used for calculation of the allowable depth which the mining shaft will tolerate without being cased. One should note that because of assumed sign convention $R_{c}<0$ in Equations (4) and (5).

\section{Derivation of basic equations using the fundamental principles of rock mechanics}

\section{State of stress at borehole wall in shale}

Before a well is drilled, the rock mass is in a certain threedimensional state of stress. Each rock element at any depth is compressed by various pressures (see Fig. 1):

- principal vertical pressure caused by the weight of overburden rocks $\left(p_{z}\right)$;

- $\quad$ principal horizontal pressures $\left(p_{2}\right.$ and $\left.p_{3}\right)$.

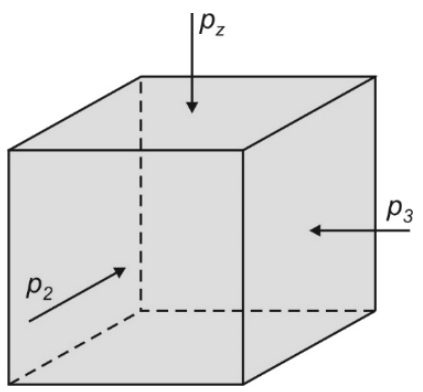

Fig. 1. Three-dimensional state of stress before drilling a well

Rys. 1. Trójosiowy stan naprężeń przed odwierceniem otworu

During drilling, the state of stress around the borehole changes, since the rocks lost the side support provided by removed material. The stresses at the borehole wall at any point $A$ on a well's circumference are as shown in Fig. 2, where: $p_{r}$ - radial pressure acting in a direction perpendicular to the tangent line at point $A$,

$p_{\theta}$ - circumferential pressure acting along tangent line at point $A$, and

$p_{z}$ - vertical pressure acting in a direction perpendicular to the cross-section plane at point $A$.

We assume that the rock behaves as an elastic material and that the destruction of rock at the borehole wall takes place

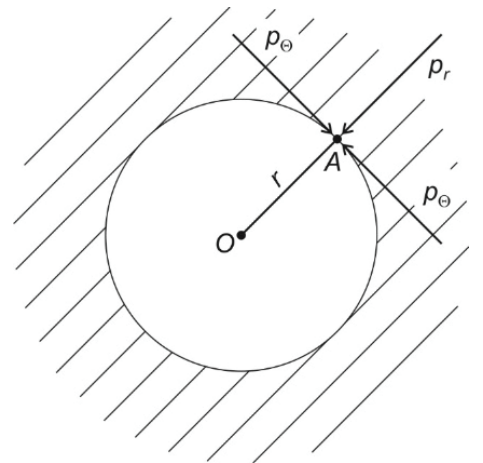

Fig. 2. The stresses at the borehole wall

Rys. 2. Naprężenia na ścianie otworu

when the stress concentration exceeds the allowable limit of material effort, which is defined here using the maximum principal strain hypothesis, which holds for brittle materials such as rocks.

The vertical pressure exerted upon any layer deposited at depth $z$ is caused by the weight of overburden rocks and equals

$$
p_{z}=\gamma_{s} z
$$

where $\gamma_{s}$ pressure gradient exerted by the overlying rocks.

It commonly believed that vertical (or overburden) pressure is opposed by both rock matrix and pore pressure, and thus the effective vertical pressure $\bar{p}_{z}$ acting on a rock matrix is

$$
\bar{p}_{z}=p_{z}-p_{0}
$$

where $p_{0}$ pore pressure.

The radial pressure at the borehole wall is caused by the tendency of a material subjected to compression to expand sideways towards the hollow space (well) and it can be calculated using the following formula (for example Huber, 1951):

$$
p_{r}=\frac{\mu}{1-\mu} \bar{p}_{z}
$$

where $\mu$ is Poisson's ratio.

The effective radial pressure at the borehole wall equals the sum of radial pressure defined by Equation (9) and pore pressure $p_{0}$ (which acts in all directions) minus the hydrostatic pressure of drilling mud $p_{m}$, which counteracts the pressures mentioned above. Thus, the effective radial pressure may be expressed as

$$
\bar{p}_{r}=\frac{\mu}{1-\mu} \bar{p}_{z}+p_{0}-p_{m}
$$

where $p_{m}$ is the hydrostatic pressure of drilling mud.

Equation (10) does not account for pressure equalisation between the rocks at the borehole face and the drilling mud. In the case of shale (and some porous rocks with extremely low permeability, such as coal) this effect may be ignored, since 
shale has a somewhat porous structure and zero permeability, which disables the flow of the mud filtrate and equalization of pressures. Thus, Equation (10) holds only for shales and other extremely low-permeability rocks such as coal.

Knowing the pressure (stress) values at the borehole wall, one can calculate the material effort using the maximum principal strain hypothesis and can tell whether the stress concentration exceeds the allowable limit.

\section{Derivation of Equations (4), (5), and (6)}

Let us assume that shale/coal destruction at the borehole wall is caused by stress concentration which exceeds the allowable effort of material. Let us consider the case of the flat, cylindrical plate of rock with outside radius $a$ and with concentric opening with radius $r_{0}$, corresponding to the well's radius (see Fig. 3) (Lame problem). We also assume that the deformation of the cylindrical plate which represents the wellbore zone is negligible for $r=a$.

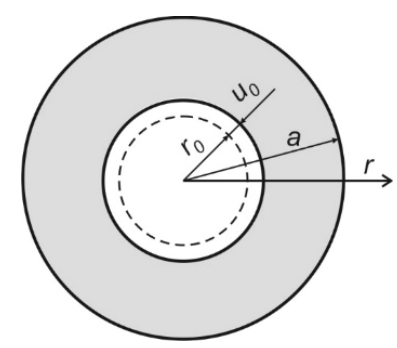

Fig. 3. Cylindrical plate of rock

Rys. 3. Cylindryczna płytka skały

The flat, cylindrical plate is compressed by overburden pressure, which causes the rock material to expand towards the hollow space, i.e. towards the well. In this case the radial and tangential stresses are given by the following equations (Huber, 1951):

$$
\begin{aligned}
& \sigma_{r}(r)=E_{1}\left[A(1+\mu)-\frac{B}{r^{2}}\left(1-\mu-2 \mu^{2}\right)\right] \\
& \sigma_{\theta}(r)=E_{1}\left[A(1+\mu)+\frac{B}{r^{2}}\left(1-\mu-2 \mu^{2}\right)\right]
\end{aligned}
$$

and the radial displacement $u(r)$ of any material point on the flat, cylindrical plate is

$$
u=A r+\frac{B}{r}
$$

The constants $A$ and $B$ are calculated using the following boundary conditions:

$$
u(a)=0
$$

$$
\sigma_{r}\left(r=r_{0}\right)=\bar{p}_{r}
$$

where $\bar{p}_{r}=\sigma_{r}\left(r=r_{0}\right)$ is defined by Equation (10).

The constants $A$ and $B$ must thus satisfy the following equations:

$$
\begin{gathered}
E_{1}\left[A(1+\mu)-\frac{B}{r^{2}}\left(1-\mu-2 \mu^{2}\right)\right]=\bar{p}_{r} \\
A a+\frac{B}{a}=0
\end{gathered}
$$

and so we have

$$
\begin{aligned}
& A=\frac{-\bar{p}_{r}}{E_{1}\left[(1+\mu)-\frac{a^{2}}{r_{0}{ }^{2}}\left(1-\mu-2 \mu^{2}\right)\right]} \\
& B=\frac{-\bar{p}_{r} a^{2}}{E_{1}\left[(1+\mu)+\frac{a^{2}}{r_{0}{ }^{2}}\left(1-\mu-2 \mu^{2}\right)\right]}
\end{aligned}
$$

where

$$
E_{1}=\frac{E}{(1+\mu)^{2}(1-2 \mu)}
$$

The radial and tangential stresses are thus equal to

$$
\begin{aligned}
& \sigma_{r}(r)=\frac{\bar{p}_{r}}{1+\frac{a^{2}}{r_{0}{ }^{2}}(1-2 \mu)}\left[1+\frac{a^{2}}{r^{2}}(1-2 \mu)\right] \\
& \sigma_{\theta}(r)=\frac{\bar{p}_{r}}{1+\frac{a^{2}}{r_{0}{ }^{2}}(1-2 \mu)}\left[1-\frac{a^{2}}{r^{2}}(1-2 \mu)\right]
\end{aligned}
$$

The radial displacement of the borehole wall - see Equations (13), (18), and (19) - can be calculated as follows:

$u\left(r_{0}\right)=A r_{0}+\frac{B}{r_{0}}=A\left(r_{0}-\frac{a^{2}}{r_{0}}\right)=A\left(\frac{r_{0}^{2}-a^{2}}{r_{0}}\right)<0$

and, as shown above, $u(r)$ grows from $u\left(r_{0}\right)<0$ to $u(a)=0$, so $\varepsilon_{r}=\frac{d u}{d r}>0$ namely:

$$
E \varepsilon_{r}=\sigma_{r}-\mu\left(\sigma_{\theta}+\sigma_{z}\right)>0
$$

Assuming the maximum principal strain hypothesis and regarding $\varepsilon_{r}$ as the maximum principal strain, we can write the following equation (Huber, 1951):

$$
\sigma_{r}-\mu\left(\sigma_{\theta}+\sigma_{z}\right)=-\mu R_{c}
$$

where $R_{c}$ unconfined compressive strength.

It follows from Equation (24) that in Equation (25) $R_{c}<0$.

Comparing (21) and (22), we have for $a>r_{0}$, i.e. $\left(\frac{r_{0}}{a}\right)^{2} \cong 0$

$$
\frac{\sigma_{r}\left(r=r_{0}\right)}{\sigma_{\theta}\left(r=r_{0}\right)} \cong-1
$$


and thus

$$
\begin{gathered}
\sigma_{r}\left(r=r_{0}\right)=\bar{p}_{r} \\
\sigma_{\theta}\left(r=r_{0}\right)=-\bar{p}_{r}
\end{gathered}
$$

Substituting (27) and (28) to (25) yields for $\sigma_{z}=p_{z}$ (Equation 8)

$$
\bar{p}_{r}-\mu\left(-\bar{p}_{r}+p_{z}\right)=-\mu R_{c}
$$

Substituting Equation (7) into Equation (10) as well as Equations (8) and (10) into Equation (29), and accounting for the fact that pore pressure $p_{0}$ and mud hydrostatic pressure $p_{m}$ are linear functions of depth $z$,

$$
\begin{aligned}
& p_{0}=\alpha z \\
& p_{m}=\gamma_{m} z
\end{aligned}
$$

we get the following equation:

$$
z_{\text {crit }}\left[\gamma_{s} \frac{2 \mu^{2}}{1-\mu^{2}}-\gamma_{p}(1+\mu)+\alpha \frac{1-3 \mu^{2}}{1-\mu^{2}}\right]=-\mu R_{c}
$$

which may be presented as shown below:

$$
z_{\text {crit }}=\frac{-\frac{\mu}{1+\mu} R_{c}}{\gamma_{s} \frac{2 \mu^{2}}{1-\mu^{2}}+\alpha \frac{1-3 \mu^{2}}{1-\mu^{2}}-\gamma_{m}}
$$

where $z_{\text {crit }}$ is the depth at which stress concentration at a borehole wall in a shale/coal horizon of known mechanical parameters $\left(R_{c}\right.$ and $\mu$ ) is equal to the maximum allowable value for a given mud pressure gradient $\gamma_{m}[\mathrm{~Pa} / \mathrm{m}]$, average pressure gradient exerted by overburden rocks $\gamma_{s}[\mathrm{~Pa} / \mathrm{m}]$, and pore pressure gradient $\alpha$.

As seen from (33), if it is possible to keep the mud density gradient equal to

$$
\gamma_{m}=\gamma_{s} \frac{2 \mu^{2}}{1-\mu^{2}}+\alpha \frac{1-3 \mu^{2}}{1-\mu^{2}}
$$

then $z_{\text {crit }}$ will be very large (theoretically infinite) and the wellbore stability will be maintained at any depth, provided $\mu, \alpha$, and $\gamma_{s}$ are constant. It is also evident from (33) that for an empty well $\left(\gamma_{m}=0\right)$ and rocks with no porosity and no pore pressure $(\alpha=0)$ we can write the following equation:

$$
z_{\text {crit }}=\frac{1-\mu}{2 \mu} \frac{R_{c}}{\gamma_{s}}
$$

which defines the depth which the mining shaft will tolerate without being cased (Kłeczek, 1985).

As we might expect (and as is shown by Equation (33)) the critical depth $z_{\text {crit }}$ increases as the rock compressive strength increases. The increase of mud weight also increases the $z_{\text {crit }}$. If the increase of mud weight gradient $\gamma_{m}$ eliminates the problem of the 'heaving' rock, then one should suppose that
- shales/coals were at a depth greater than $z_{\text {crit }}$ and the stress concentration at the borehole wall exceeded the allowable value causing 'heaving';

- an increase of mud weight caused an increase of $z_{\text {crit }}$ large enough to drop the stress concentration below the allowable limit.

It is common practice to increase the mud weight when drilling in a heaving shale horizon - this supports the conclusions provided herein.

The large pressure gradient of overburden rocks $\gamma_{s}$ (and pore pressure gradient $\alpha$ in particular) decreases $z_{\text {crit }}$. The Poisson's ratio from shale specific range $0.19-0.25$ doesn't strongly impact $z_{\text {crit }}$, which decreases with increase of $\mu$.

The model presented herein may also be used to derive a formula for fracturing pressure and fracture gradient. Indeed, substituting Equation (10) into Equation (28) and taking into account Equations (8), (7), (30), and (31) yields the following formula for circumferential pressure at a borehole wall at depth $z$ :

$$
\sigma_{\theta}=-\bar{p}_{r_{0}}=-z\left[\frac{\mu}{1-\mu}\left(\gamma_{s}-\alpha\right)+\alpha-\gamma_{m}\right]
$$

where $\sigma_{\theta}$ is the compressive stress in a well filled with mud (see Fig. 2).

Increasing the wellbore pressure at that depth decreases the compressive circumferential stress at the borehole wall, which may become tensional stress if the wellbore pressure increase is large enough. Because the tensional strength of rocks is assumed to be zero, fracturing occurs at that wellbore pressure, which reduces to zero the circumferential stress at the borehole wall. The $\gamma_{m}$ value for which $\sigma_{r}=\left|-\bar{p}_{r_{0}}\right|=0$ thus corresponds to fracturing pressure $p_{\text {frac }}$ and we have from Equation (36)

$$
p_{\text {frac }}=z\left[\frac{\mu}{1-\mu}\left(\gamma_{s}-\alpha\right)+\alpha\right]
$$

which is the well-known Hubbert-Willis formula.

\section{Laboratory measurements}

\section{Strength tests}

The unconfined compressive strength $R_{c}$ and Poisson's ratio $\mu$ were measured using circular samples cut from the cores and an MTS 815 hydraulic press from MTS Systems Corporation. The measurements were carried out following the recommendations of the Polish Standard PN-EN 1926.

\section{Measurements of swelling pressure}

The swelling pressures were measured using an INiG - PIB modified edometer, which is routinely used for evaluating 


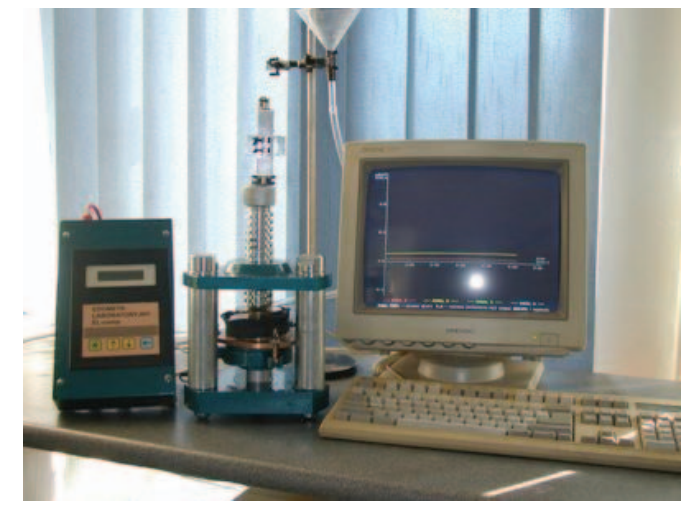

Fig. 4. Apparatus for measuring the swelling pressure of silty rocks and shales (edometer)

Rys. 4. Aparat do pomiaru ciśnienia pęcznienia skał ilastych i łupków (edometr)

the swelling pressure of silty rocks subjected to compression (Fig. 4). The test samples were made from ground silt/shale powder which was passed in advance through a sieve with an appropriate mesh. The silt/shale powder was used to produce tablets which were kept in a tight container to keep them at a constant humidity. These tablets were placed in a measuring cell where they were exposed to various liquids or solutions. The swelling pressures provided in this paper were measured using water, for which those pressures are the greatest. The results are presented in Table 1 together with calculation data for the analysed wells.

\section{Examples of well stability calculations}

In the well E-1, drilled in the Carpathians, the heaving shale was encountered in the depth interval of 1650-1750 m. We assume an average shale depth $z$ of $1700 \mathrm{~m}$. The shale's compressive strength $R_{c}$ - evaluated using cores from similar, nearby shale rocks - was $12 \mathrm{MPa}$ and the average Poisson's ratio from full-phase sonic logs was 0.21 . The pore pressure was equal to $20.7 \mathrm{MPa}$. The average density of overburden rocks was $2300 \mathrm{~kg} / \mathrm{m}^{3}$ and the density of the mud in the well was $1200 \mathrm{~kg} / \mathrm{m}^{3}$. We aimed to answer the following questions:

a) Is it possible to maintain the mechanical integrity of shale at this depth?

The critical depth of shale is calculated using Equation (4):

$$
z_{\text {crit }}=1524 \mathrm{~m}
$$

which shows that the stress concentration at the borehole wall at $1700 \mathrm{~m}$ is above the allowable limit since $z>z_{\text {crit }}$ (which means that the actual shale depth $z$ is greater than the critical depth), and so a shale with those strength properties is not able to maintain its integrity in such conditions (i.e. the actual mud density, average density of overburden rocks, rock mechanical parameters, and pore pressure gradient) which is manifested by shale crushing at the borehole wall. b) What is the minimum mud density required to assure shale integrity at a specified depth?

The minimum mud density required to maintain shale integrity at a depth $z$ of $1700 \mathrm{~m}$ is calculated using Equation (5), in which the actual depth of the shale horizon is substituted for the critical depth.

$$
\rho_{m \text { min }}=1214\left[\frac{\mathrm{kg}}{\mathrm{m}^{3}}\right]
$$

The calculation indicates that the mud density should be increased from the actual mud density, $1200 \mathrm{~kg} / \mathrm{m}^{3}$, to $1214 \mathrm{~kg} / \mathrm{m}^{3}$ in order to ensure shale integrity at $z=1700 \mathrm{~m}$.

c) For which mud density would a shale with the abovespecified strength properties preserve its integrity at any depth for a constant pore pressure gradient and a constant average density of overburden rocks?

The mud density for which a shale with these strength properties would preserve its integrity at any depth assuming constant $\rho_{s}$ and $\alpha$ can be calculated using Equation (6):

$$
\rho_{m_{\max }}=1339\left[\frac{\mathrm{kg}}{\mathrm{m}^{3}}\right]
$$

The resulting value is the mud density for which stress concentration at the borehole wall would not exceed the allowable limit at any depth for shale with specified strength properties, constant pore pressure gradient, and constant overburden pressure gradient.

The results of calculations carried out using this procedure for several wells from the south of Poland are presented in Table 1. The unconfined compressive strength and swelling pressures were measured as described earlier. The calculations for some coal wells from Upper Silesia are also provided. In all cases the average density of overburden rocks was assumed to be $2300 \mathrm{~kg} / \mathrm{m}^{3}$.

As shown, the swelling pressure has a large impact on the pore pressure gradient. In the analysed samples the pore pressure gradient increased from 0.0002 to $0.0099 \mathrm{MPa} / \mathrm{m}$.

For six of the analysed cases, the well instability was related to excessive depth and for the next six wells the mud density could be increased to solve the problem. In the case of coal deposits, the risk of well collapse was anticipated in one case, due to the excessive depth of the coal deposit.

\section{Advantages and disadvantages of the presented approach}

\section{Advantages}

- The greatest merit of this approach is its simplicity. The presented procedure allows us to tell whether the shale/ coal will maintain its integrity at an actual depth $z$ as well 
Table. 1. Results of calculations for wells drilled in shale and coal formations

Tabela 1. Wyniki obliczeń dla otworów przewiercających utwory łupków i węgli

\begin{tabular}{|c|c|c|c|c|c|c|c|c|c|c|c|c|}
\hline \multirow{3}{*}{$\overline{\overline{0}}$} & \multirow{3}{*}{$\begin{array}{l}\frac{1}{0} \\
0 \\
0 \\
0 \\
0 \\
0 \\
0\end{array}$} & \multirow{3}{*}{ 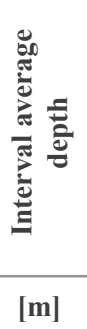 } & \multirow{3}{*}{ 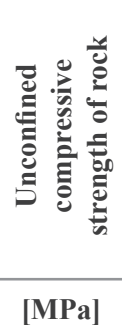 } & \multirow{3}{*}{ 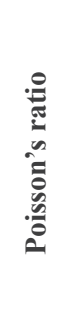 } & \multirow{2}{*}{ 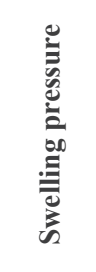 } & \multicolumn{2}{|c|}{ Pore pressure gradient } & \multirow{2}{*}{ 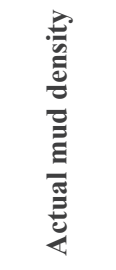 } & \multirow{2}{*}{ } & \multirow{2}{*}{ 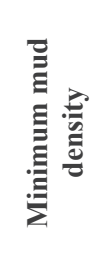 } & \multirow[b]{2}{*}{ 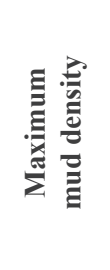 } & \multirow{2}{*}{ 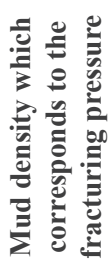 } \\
\hline & & & & & & 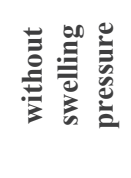 & 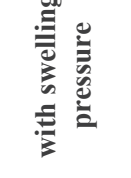 & & & & & \\
\hline & & & & & [MPa] & {$[\mathbf{M P a} / \mathbf{m}]$} & {$[\mathrm{MPa} / \mathrm{m}]$} & {$\left[\mathrm{kg} / \mathrm{m}^{3}\right]$} & {$[\mathrm{m}]$} & {$\left[\mathrm{kg} / \mathrm{m}^{3}\right]$} & {$\left[\mathrm{kg} / \mathrm{m}^{3}\right]$} & {$\left[\mathrm{kg} / \mathrm{m}^{3}\right]$} \\
\hline Dr-3 & \multirow{32}{*}{ shale } & 518 & 27.40 & 0.23 & 4.61 & 0.0115 & 0.0214 & $1150 * *$ & 502 & 1182 & 2191 & 2214 \\
\hline Dy-1 & & 4201 & 53.94 & 0.30 & 4.19 & 0.0112 & 0.0122 & 1300 & 8419 & 1149 & 1451 & 1695 \\
\hline $\mathrm{J}-33$ & & 1293 & 30.40 & 0.25 & 4.46 & 0.0105 & 0.0140 & 1200 & 1826 & 1060 & 1540 & 1715 \\
\hline $\mathrm{Ki}-12$ & & 2239 & 36.29 & 0.25 & 2.54 & 0.0107 & 0.0118 & 1200 & 4851 & 1022 & 1353 & 1571 \\
\hline $\mathrm{Kr}-3$ & & 1150 & 17.65 & 0.22 & 3.14 & 0.0107 & 0.0134 & 1190 & 1184 & 1182 & 1464 & 1632 \\
\hline L-7 & & 1784 & 33.43 & 0.25 & 1.49 & 0.0111 & 0.0119 & 1200 & 4317 & 976 & 1358 & 1575 \\
\hline \multirow{2}{*}{ M-4 } & & 810 & 18.63 & 0.19 & 5.78 & 0.0113 & 0.0184 & 1500 & 744 & 1533 & 1908 & 1975 \\
\hline & & 943 & 22.56 & 0.21 & 9.21 & 0.0118 & 0.0216 & 1800 & 976 & 1785 & 2209 & 2226 \\
\hline N-1 & & 4782 & 59.82 & 0.35 & 1.19 & 0.0112 & 0.0114 & 1300 & 8611 & 1153 & 1484 & 1777 \\
\hline O-17 & & 1336 & 26.48 & 0.20 & 12.68 & 0.0105 & 0.0200 & 1600 & 978 & 1723 & 2060 & 2104 \\
\hline \multirow{2}{*}{ P-4 } & & 773 & 18.63 & 0.21 & 2.89 & 0.0103 & 0.0140 & 1200 & 1058 & 1085 & 1512 & 1662 \\
\hline & & 1009 & 22.56 & 0.25 & 2.97 & 0.0104 & 0.0133 & 1200 & 1609 & 1030 & 1486 & 1674 \\
\hline \multirow{2}{*}{ R-1 } & & 1559 & 21.58 & 0.20 & 13.21 & 0.0105 & 0.0190 & $1700^{* *}$ & 1383 & 1730 & 1965 & 2026 \\
\hline & & 1669 & 21.58 & 0.20 & 9.72 & 0.0105 & 0.0163 & $1200^{* *}$ & 709 & 1498 & 1718 & 1823 \\
\hline \multirow{9}{*}{ S-8 } & & 650 & 44.13 & 0.22 & 3.24 & 0.0131 & 0.0181 & 1600 & 2780 & 643 & 1892 & 1974 \\
\hline & & 778 & 33.34 & 0.22 & 3.91 & 0.0129 & 0.0179 & 1600 & 2241 & 1086 & 1874 & 1959 \\
\hline & & 1492 & 35.31 & 0.22 & 7.85 & 0.0145 & 0.0198 & 1900 & 4398 & 1612 & 2048 & 2098 \\
\hline & & 1561 & 37.27 & 0.22 & 10.81 & 0.0125 & 0.0194 & 2200 & $-^{*}$ & 1572 & 2011 & 2069 \\
\hline & & 1856 & 37.27 & 0.23 & 5.64 & 0.0166 & 0.0196 & 2200 & $-^{*}$ & 1649 & 2032 & 2089 \\
\hline & & 1895 & 39.76 & 0.23 & 7.16 & 0.0158 & 0.0196 & 2200 & $-^{*}$ & 1632 & 2032 & 2089 \\
\hline & & 1937 & 40.21 & 0.23 & 5.01 & 0.0171 & 0.0197 & 2200 & $-^{*}$ & 1646 & 2041 & 2096 \\
\hline & & 1979 & 40.98 & 0.23 & 4.53 & 0.0165 & 0.0188 & 2100 & $-^{*}$ & 1564 & 1959 & 2031 \\
\hline & & 1999 & 41.19 & 0.23 & 4.14 & 0.0196 & 0.0217 & 2100 & 6564 & 1827 & 2220 & 2237 \\
\hline Sw-4 & & 3577 & 37.52 & 0.26 & 3.14 & 0.0104 & 0.0113 & 2320 & $-^{*}$ & 1094 & 1315 & 1552 \\
\hline Tu-2 & & 633 & 18.63 & 0.22 & 5.81 & 0.0103 & 0.0195 & $1450^{* *}$ & 602 & 1477 & 2019 & 2075 \\
\hline Ty-1 & & 1920 & 22.56 & 0.22 & 8.14 & 0.0107 & 0.0149 & $1100^{* *}$ & 826 & 1386 & 1602 & 1742 \\
\hline \multirow{3}{*}{ W-3 } & & 1375 & 36.29 & 0.25 & 2.28 & 0.0105 & 0.0124 & 1300 & 7485 & 860 & 1399 & 1607 \\
\hline & & 842 & 20.60 & 0.23 & 2.12 & 0.0101 & 0.0128 & 1200 & 1802 & 951 & 1418 & 1604 \\
\hline & & 1078 & 24.52 & 0.25 & 6.64 & 0.0103 & 0.0167 & $1300^{* *}$ & 1044 & 1315 & 1779 & 1899 \\
\hline $\mathrm{Z}-2$ & & 3215 & 44.02 & 0.27 & 0.19 & 0.0105 & 0.0114 & 1200 & 6828 & 1043 & 1340 & 1582 \\
\hline $\mathrm{Z}-3$ & & 2916 & 28.83 & 0.28 & 2.35 & 0.0119 & 0.0127 & 1180 & 2266 & 1243 & 1464 & 1684 \\
\hline Z-8 & & 1391 & 35.30 & 0.27 & 4.35 & 0.0103 & 0.0136 & 1200 & 2300 & 983 & 1533 & 1726 \\
\hline \multirow{9}{*}{$\begin{array}{l}\text { MS- } \\
501\end{array}$} & \multirow{2}{*}{ semi-gloss coal } & 953.4 & 15.10 & 0.17 & - & 0.0103 & - & 1020 & 2137 & 890 & 1125 & 1306 \\
\hline & & 957.1 & 15.20 & 0.38 & - & 0.0103 & - & $1020^{* *}$ & 944 & 1026 & 1472 & 1816 \\
\hline & coal matt & 961.1 & 31.70 & 0.26 & - & 0.0103 & - & 1020 & 3154 & 538 & 1232 & 1489 \\
\hline & \multirow{4}{*}{ semi-gloss coal } & 963.5 & 24.70 & 0.34 & - & 0.0103 & - & 1020 & 1790 & 714 & 1377 & 1694 \\
\hline & & 966.7 & 26.20 & 0.31 & - & 0.0103 & - & 1020 & 2136 & 662 & 1316 & 1612 \\
\hline & & 971.6 & 27.50 & 0.26 & - & 0.0103 & - & 1020 & 2736 & 636 & 1232 & 1489 \\
\hline & & 974.3 & 23.90 & 0.30 & - & 0.0103 & - & 1020 & 2027 & 720 & 1297 & 1586 \\
\hline & semi-gloss hard coal & 978.4 & 22.30 & 0.31 & - & 0.0103 & - & 1020 & 1818 & 766 & 1316 & 1612 \\
\hline & coal matt & 980.4 & 34.70 & 0.30 & - & 0.0103 & - & 1020 & 2943 & 465 & 1297 & 1586 \\
\hline
\end{tabular}

" risk of the collapse

*** mud density should be increased above the minimum mud density 
as the range of mud density that is required to eliminate wellbore stability problems.

\section{Disadvantages}

- One never knows the true reason for shale problems - whether they are mechanical in nature or are caused by the chemical interaction between mud and shale/coal; thus, it is difficult to provide numerous examples to support the conclusions provided herein. We believe that the mechanical aspects should be considered first, since well stability cannot be assured regardless of the type of mud being used - if the combination of the mechanical properties and depth of the shale/coal and the mud density and pore pressure is not favourable.

- This approach may be considered oversimplified, but it does allow for an approximation of some important practical values.

\section{Conclusion}

It is difficult to indicate a single reason for loss of well integrity in a shale/coal interval since there are many factors which influence shale's behaviour - mud compatibility being the most important. As mentioned above, the problem of well integrity in shales has been extensively discussed in the technical literature. We believe that apart from mud chemistry and chemical interactions with shale, there are situations when a loss of shale integrity should be considered due to rock mechanics. Many models have been presented and numerous papers have dealt with well stability problems in shale (Lechnickij, 1958; Bruce and Hall, 1986; Ottesen and Kwakwa, 1991; Santarelli et al, 1992; Mody and Hale, 1993; Van Oort et. al., 1994; Cook and Thiercelin, 1995; Lowrey and Ottesen, 1995; Santarelli and Carminati, 1995), but they share two common features: they are complicated and difficult to use in practice.

The model presented herein, being quite simple, is easy to apply and the results seem reasonable.

Acknowledgments: The paper was prepared on the grounds of international project Advanced methane drainage strategytechnology employing underground directional drilling technology for major risk prevention and greenhouse gases emission mitigation, which is co-founded by the programme of the Minister of Science and Higher Education entitled $P M W$ in 2019-2022. Agreement no. 5038/FBWiS/2019/2.

This project has received co-funding from the Research Fund for Coal and Steel under grant agreement no. 847338.

\section{References}

Bruce S., Hall C., 1986. The stability of boreholes. Drilling and Pumping Journal.
Cook J., Thiercelin M., 1995. The mechanics of shale. Schlumberger Cambridge Research.

Gomez S., He W., 2012. Fighting Wellbore Instability: Customizing Drilling Fluids Based on Laboratory Studies of Shale-Fluid Interactions. IADC/SPE Asia Pacific Drilling Technology Conference and Exhibition, Tianjin, China. DOI: 10.2118/155536-MS.

Huber T.M., 1951. Technical Stereomechanics. PAN, Warszawa.

Kłeczek Z., 1985. Rock mechanics. Skrypty AGH, Kraków.

Koteeswaran S., Habibpour M., Puckette J., Pashin J.C., Clark P.E., 2018. Characterization of shale-fluid interaction through a series of immersion tests and rheological studies. Journal of Petroleum Exploration and Production Technology, 8: 1273-1286. DOI: 10.1007/ s13202-018-0444-5.

Lechnickij S.G., 1958. Opridielenie naprazenij w uprugom isotropnom massivie v blizi vertikalnej cylindriczeskoj wyrabotki kruglovo seczenija. Izvestija ANZSRR, OTN, 7.

Lowrey J.P., Ottesen S., 1995. An assessment of the mechanical stability of wells offshore Nigeria. SPE Drilling \& Completion, 10(1). DOI: 10.2118/26351-PA.

Lyu Q., Ranjith P.G., Long X., Kang Y., Huang M., 2015. A review of shale swelling by water adsorption. Journal of Natural Gas Science and Engineering, 27(11): 1421-1431. DOI: 10.1016/j.jngse.2015.10.004.

Mody F.K., Hale A.H., 1993. Borehole-Stability Model to Couple the Mechanics and Chemistry of Drilling-Fluid/Shale Interactions. Society of Petroleum Engineers, 45(11): 1093-1101. DOI: 10.2118/25728-PA.

Ottesen S., Kwakwa K.A., 1991. Multidisciplinary Approach to insitu Stress Determination and its Application to Wellbore Stability Analysis. Society of Petroleum Engineers SPE-21915-MS. DOI: 10.2118/21915-MS.

Santarelli F.J, Carminati S., 1995. Do shales swell? A critical review of available evidence. SPE Conference Paper. Society of Petroleum Engineers. DOI: 10.2118/29421-MS.

Santarelli F.J., Chenevert M.E., Osisanya S.O., 1992. On the stability of shales and its consequences in terms of swelling and wellbore stability. IADC/SPE Drilling Conference, New Orleans. DOI: 10.2118/23886-MS

Van Oort E., Hale A.H., Mody F.K., 1994. Critical parameters in modelling the chemical aspects of borehole stability in shales and in designing improved water-based shale drilling fluids. SPE Annual Conference and Exhibition, New Orlean. Conference Paper: 171-186.

Wang L.L., Zhang G.Q., Hallais S., Tanguy A., Yang D.S., 2017. Swelling of Shales: A Multiscale Experimental Investigation. Energy \& Fuels: 31(10): 10442-10451. DOI: 10.1021/acs.energyfuels.7b01223.

\section{Legislative acts and normative documents}

Standard PN-EN 1926:2007 (PN-EN 1926). Metody badań kamienia naturalnego - Oznaczanie jednoosiowej wytrzymałości na ściskanie.

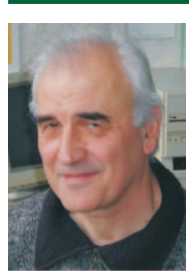

Dr inż. Tadeusz SZPUNAR

Adiunkt w Zakładzie Inżynierii Naftowej

Instytut Nafty i Gazu - Państwowy Instytut Badawczy

ul. Lubicz 25 A

31-503 Kraków

E-mail: tadeusz.szpunar@inig.pl

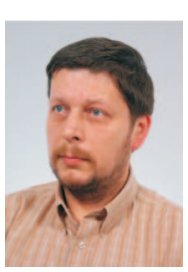

Mgr inż. Paweł BUDAK

Starszy specjalista naukowo-badawczy,

kierownik Zakładu Inżynierii Naftowej

Instytut Nafty i Gazu - Państwowy Instytut Badawczy

ul. Lubicz $25 \mathrm{~A}$

31-503 Kraków

E-mail:pawel.budak@inig.pl 